\title{
PENERAPAN AKUNTANSI PENYUSUTAN ASET TETAP BERDASARKAN PERNYATAAN STANDAR AKUNTANSI PEMERINTAH NOMOR O7 PADA DINAS PEKERJAAN UMUM PROVINSI SUAWESI UTARA
}

\author{
Sahril Rumbaru ${ }^{1}$, Inggriani Elim², Meily Y. B Kalalo ${ }^{3}$ \\ 1,2,3 Jurusan Akuntansi, Fakultas Ekonomi dan Bisnis, Universitas Sam Ratulangi, Jl. Kampus Bahu, Manado, \\ 95115, Indonesia \\ E-mail : rumbarusahril@gmail.com
}

\begin{abstract}
Statement of Government Accounting Standards (PSAP) 07 is the accounting standard for property, plant and equipment including recognition, determination of carrying amount, accounting treatment of revaluation and impairment of carrying value of property and equipment. This study aims to determine the suitability of the application of accounting depreciation of fixed asset based on PSAP 07 at the Public Works Department of North Sulawesi Province. The data used is the report of depreciation in fiscal year 2016. The method used is descriptive analysis method. The results of the research indicate that the Public Works Agency in the application of fixed asset depreciation, the determination of depreciation value, the useful life of the asset, the use of depreciation method and the determination of the book value of the asset is in accordance with PSAP 07, however in the implementation of recording into reporting depreciation of fixed assets, has not implemented it independently but is done by the Regional Financial Management and Asset Board (BPKAD) of North Sulawesi Province somehow it is not in accordance with the assumption of entity independence in Government Regulation Number 71 of 2010 on Government Accounting Standards. It is expected that the Public Works Department of North Sulawesi Province may apply accounting for depreciation in accordance into applicable regulations. Keywords : PSAP 07, Depreciation of Fixed Asset, Implementation of Depreciation
\end{abstract}

\section{PENDAHULUAN}

Dengan diterbitkan Standar Akuntansi Pemerintah dalam Peraturan Pemerintah Nomor 24 Tahun 2005 yang telah dirubah menjadi Peraturan Pemerintah Nomor 71 Tahun 2010 terdiri dari dua belas pernyataan standar akuntansi pemerintah, yang menjadi pedoman bagi pemerintah daerah dalam melakukan pertanggungjawaban pengelolaan keuangan daerah. Salah satu dari dua belas pernyataan standar akuntansi pemerintah tersebut, terdapat satu standar yang secara khusus mengatur pengelolaan aset tetap, standar tersebut adalah Pernyataan Standar Akuntansi Pemerintah (PSAP) Nomor 07 mengenai akuntansi aset tetap. Tujuan dari standar ini adalah mengatur perlakuan akuntansi untuk aset tetap meliputi pengakuan, penetuan nilai tercatat, serta penentuan dan perlakuan akuntansi atas penilaian kembali dan penurunan nilai tercatat (carrying value) aset tetap. Aset tetap merupakan bagian daripada unsur penting sehingga memerlukan pengelolaan yang baik untuk menghasilkan informasi yang relevan dalam laporan keuangan pemerintah daerah. Pengelolan aset daerah merupakan sesuatu yang harus dilakukan secara baik agar dapat memberikan gambaran tentang kekayaan daerah, terdapt kejelasan status kepemilikan, pengamanan barang milik daerah peningkatan Pendapatan Asli Daerah (PAD) dengan pemanfaatan aset daerah yang ada serta digunakan untuk dasar penyajian laporan keuangan pemerintah. Aset tetap perlu dikelola dengan baik sehingga pengelolaan aset daerah yang transparan, akuntanbel, efisien dapat terwujudkan, serta adanya kepastian nilai yang berfungsi sesuai dengan tugas pokok dan fungsi pemerintah daerah, (Yusuf, 2011: 11). Salah satu aspek penting dalam 
pengelolaan aset tetap yaitu penyusutan yang meliputi perhitungan dan pelaporan penyusutan. Menurut Mursyidi (2009:211) penyusutan memungkinkan pemerintah mendapatkan informasi tentang potensi aset tetap yang dimilikinya. Nilai aktiva tetap harus disusutkan setiap periodenya oleh pengguna aset, sehingga dapat menggambarkan potensi sebenarnya dari aktiva tetap tersebut.

Dinas Pekerjaan Umum Provinsi Sulawesi Utara adalah salah satu entitas publik di lingkungan Pemerintah Provinsi Sulawesi Utara yang berkewajiban penuh untuk menerapkan akuntansi penyusutan sesuai dengan yang telah diamanahkan dalam Peraturan Pemerintah No 71 Tahun 2010. Berdasarkan latar belakang masalah yang telah diuraikan, maka perumusan masalah adalah Bagaimana penerapan akuntansi penyusutuan aset tetap berdasarkan Pernyataan Standar Akuntansi Pemerintah Nomor 07 pada Dinas Pekerjaan Umum Provinsi Sulawesi Utara? Tujuan Penelitian ini adalah untuk mengetahui penerapan akuntansi penyusutuan aset tetap berdasarkan Pernyataan Standar Akuntansi Pemerintah nomor 07 pada Dinas Pekerjaan Umum Provinsi Sulawesi Utara.

\section{TINJAUAN PUSTAKA}

\subsection{Pengertian Akuntansi}

Horgen et al (2012) dalam Pontoh (2013) menyatakan Akuntansi adalah sebuah system informasi yang mengukur aktifitas bisnis, memproses data suatu kejadian ekonomi menjadi laporan, dan mengkomunikasikan hasilnya kepada para pengambil keputusan.

\subsection{Akuntansi Pemerintah}

Akuntansi pemerintah merupakan bagian dari akuntansi sektor publik. Akuntansi pemerintah adalah akuntansi yang bersangkutan dengan bidang keuangan Negara, dari anggaran sampai dengan pelaksanaan dan pelaporannya, termasuk segala pengaruh yang ditimbulkannya (Sujarweni, $2016: 18$ ).

\subsection{Aset Tetap}

Aset tetap (fixed assets) adalah aset yang bersifat jangka panjang atau relative memiliki sifat permanen serta dapat digunakan dalam jangka panjang. Aset ini merupakan aset berwujud karena memiliki bentuk fisik. Aset ini dimiliki dan digunakan oleh instansi dan tidak dijual sebagai bagian dari kegiatan operasional normal. Nama lain yang digunakan dalam bahasa inggis untuk aset tetap adalah plant assets, property, plant, and equipment (PPE) (Reeve. Et al.2013:2).

\subsection{Asumsi Dasar Dalam Pelaporan Keuangan Pemerintah}

Dalam Peraturan Pemerintah nomor 71 tahun 2010 menjelaskan bahwa Asumsi dasar dalam pelaporan keuangan di lingkungan pemerintah adalah anggapan yang diterima sebagai suatu kebenaran tanpa perlu dibuktikan agar standar akuntansi dapat diterapkan, yang terdiri dari:

1. Asumsi kemandirian entitas;

2. Asumsi kesinambungan entitas; dan

3. Asumsi keterukuran dalam satuan uang (monetary measurement)

\subsection{Pernyataan Standar Akuntansi Pemerintah (PSAP) No 07}

Dalam Peraturan Pemerintah Nomor 71 Tahun 2010 Tentang Standar Akuntansi Pemerintah dijelaskan bahwa Standar Akuntansi Pemerintah (SAP) adalah prinsip-prinsip akuntansi yang digunakan dalam menyusun dan menyajikan laporan keuangan pemerintah. Pernyataan Standar Akuntansi Pemerintah yang disingkat PSAP adalah SAP yang diberi judul, nomor dan tanggal efektif. Buletin Teknis SAP adalah informasi mengenai penjelasan teknis akuntansi sebgia pedoman bagi pengguna.

Tujuan Pernyataan Standar Akuntansi Pemerintah Nomor 07 adalah untuk mengatur perlakuan akuntansi untuk aset tetap meliputi pengakuan, penentuan nilai tercatat, serta 
penentuan dan perlakuan akuntansi atas penilaian kembali dan penurunan nilai tercatat (carrying value) aset tetap (PP No 71 Tahun 2010).

\subsection{Penyusutan}

Pernyataan Standar Akuntansi Pemerintahan (PSAP 07) menjelaskan penyusutan sebagai penyesuaian nilai yang berhubungan dengan penurunan kapasitas dan manfaat dari suatu asset. Pencatatan penyusutan ini merupakan salah satu penanda diberlakukannya basis akrual dalam SAP. PSAP 07 mengatur penyusutan aset tetap pada bagian pengukuran dan penyajiannya pada periode setelah pengakuan awal nilai suatu asset.

\subsection{Metode Penyusutan}

Dalam Pernyataan Standar Akuntansi Pemerintah Nomor 07 tentang Aset Tetap, disarankan tiga metode penyusutan. Entitas pemerintah dapat menggunakan salah satu dari ketiga metode tersebut. Metode yang disarankan adalah:

a.) Metode Garis Lurus

Tarif penyusutan aset dihitung dengan rumus:

Penyusutan per periode $=\frac{\text { Nilai yang dapat disusutkan }}{\text { Masa manfaat }}$

b) Metode Saldo Menurun Berganda

(Nilai yang dapat disusutkan - Akumulai penyusutan sebelum) tarif Penyusutan

Tarif penyusutan dihitung dengan rumus:

$\begin{array}{cccc}1 & \text { Masa Manfaat } & 100 \% & \text { x }\end{array}$

c) Metode Unit Produksi

Penyusutan per periode $=$ Produksi periode berjalan $\quad$ Tarif Penyusutan

Tarif penyusutan aset dihitung dengan rumus:

Nilai yang disusutkan

Perkiraan total output

\subsection{Penelitian Terdahulu}

M. Ady Soepiansyah (2014), dengan penelitian berjudul Implementasi Pernyataan Standar Akuntansi Pemerintah No. 07 Tentang Akuntansi Penyusutan Aset Tetap Pada Kantor Satuan Polisi Pamong Praja Provinsi Kalimantan Barat. Hasil penelitian menunjukan pelaksanaan akuntansi penyusutan aset tetap belum dilakukan sesuai dengan peraturan pemerintah nomor 71 tahun 2010 dan pernyataan standar akuntansi pemerintah nomor 07 . Persamaannya dengan penelitian ini adalah meneliti tentang perlakuan penyusutan aset tetap pemerintah. Perbedaanya penelitian ini ingin membahas lebih khusus mengenai penerapan aturan dalam Pernyataan Standar Akuntansi Pemerintah No 07 dan juga objek penelitian.

Akhyar Tipan (2016), penelitian dengan judul Analisis Perlakuan Akuntansi Aset Tetap Pada Dinas Pekerjaan Umum Provinsi Sulawesi Utara. Hasil penelitian menunjukan bahwa dalam pengelolaan aset tetap pada Dinas Pekerjaan Umum Provinsi Sulawesi Utara telah sesuai dengan PSAP No. 07, namun belum menerapkan penyusutan aset sesuai dengan PSAP No.07. Persamaannya dengan penelitian ini adalah menganalisis perlakuan akuntansi aset tetap berdasarkan PSAP 07. Perbedaanya adalah penelitian ini lebih khusus tentang penerapan aturan akuntansi penyusutan aset tetap 


\section{METODE PENELITIAN}

\subsection{Jenis Penelitian}

Penelitian tentang Penerapan Perhitungan Akuntansi Penyusutan Aset Tetap Berdasarkan Pernyataan Standar Akuntansi Pemerintahan Nomor 07 Pada Dinas Pekerjaan Umum Provinsi Sulawesi Utara merupakan penelitian kualitatif dengan pendekatan analisis data deskriptif, dimana proses pengumpulan data melalui wawancara, observasi, dan dokumentasi di Kantor Dinas Pekerjaan Umum Provinsi Sulawesi Utara.

\subsection{Tempat dan Waktu Penelitian}

Penelitian ini dilaksanakan pada Dinas Pekerjaan Umum Provinsi Sulawesi Utara, Jln Tikala Ares No 80, Kelurahan Tikala Ares, Kecamatan Tikala. Penelitian ini dilakukan dalam kurun waktu dua bulan, mulai bulan maret hingga April 2017.

\subsection{Prosedur Penelitian}

Langkah-langkah yang telah dilakukan pada pelaksanaan penelitian yaitu sebagai berikut.

1. Menentukan judul penelitian dan merumuskan masalah dengan jelas.

2. Pengumpulan data melalui wawancara terhadap pihak-pihak yang terkait serta pengambilan data-data mengenai penyusutan aset tetap di Dinas Pekerjaan Umum Provinsi Sulawesi Utara dan Badan Pengelolaan Keuangan dan Aset Daerah Provinsi Sulawesi Utara.

3. Mengelola data dan menginterpretasikan hasil pengelolaan data

4. Menarik kesimpulan dan memberikan saran yang dianggap perlu sebagai perbaikan dalam masalah yang ada.

\subsection{Metode Pengumpulan Data}

Data merupakan sekumpulan informasi yang diperlukan untuk pengambilan keputusan. Jenis data yang digunakan pada penelitian ini yaitu deskriptif kuantitatif. Sumber data dalam penelitian ini adalah data primer dan data sekunder. Sumber data primer dalam penelitian ini yaitu melakukan penelitian lansung pada Dinas Pekerjaan Umum Provinsi Sulawesi Utara untuk mendapatkan data berupa laporan penyusutan aset tetap pada beberapa tahun terakhir. Sumber Sumber data sekunder dalam penelitian ini yaitu diperoleh dari bukubuku, pencarian informasi internet, Pernyataan Standar Akuntansi Pemerintahan dan Peraturan Pemerintah Nomor 71 Tahun 2010 yang berlaku umum.

\subsection{Metode Analisis Data}

Metode analisis data yang digunakan ialah deskriptif, dimana data dikumpulkan, disusun, diinterpretasikan dan dianalisis sehingga memberikan keterangan yang lengkap bagi masalah yang dihadapi. Dengan cara :

1. Memaparkan hasil penelitian dari Dinas Pekerjaan Umum yang berhubungan dengan aktivitas akuntansi penyusutan aset tetap.

2. Mengevaluasi penerapan akuntansi penyusutan berdasarkan Pernyataan Standar Akuntansi Nomor 7 dan Peraturan Pemerintah Nomor 10 Tahun 2010 tentang Standar Akuntansi Pemerintah pada Dinas Pekerjaan Umum Provinsi Sulawesi Utara.

3. Memberikan kesimpulan akhir dan saran terhadap pengembangan akuntansi penyusutan aset tetap di Dinas Pekerjaan Umum Provinsi Sulawesi Utara.

Data-data yang dianalisis berupa data laporan penyusutan aset tetap, nilai perolehan aset serta masa manfaat aset.

\section{HASIL PENELITIAN DAN PEMBAHASAN}

\subsection{Hasil Penelitian}

Berdasarkan hasil wawancara dan di Dinas Pekerjaan Umum Provinsi Sulawesi Utara, kebijakan akuntansi penyusutan aset tetap dilakukan oleh lembaga lain dalam hal ini Badan Pengelolaan Aset dan Keuangan Daerah Provinsi Sulawesi Utara. BPKAD Provinsi Sulawesi 
Utara melakukan perlakuan akuntansi penyusutan secara keseluruhan mulai dari penyediaan kartu inventaris barang, perhitungan penyusutan aset hingga pelaporan penyusutan aset.

Berdasarkan penjelasan dari pengurus barang SKPD Dinas Pekerjaan Umum Provinsi Sulawesi Utara, akumulasi penyusutan aset sebenarnya tidak dikelola sendiri oleh pihak Dinas Pekerjaan Umum Provinsi Sulawesi Utara melainkan hanya memakai aplikasi SIMDA dari Badan Pengelola Keuangan dan Aset (BPKAD) Sulawesi Utara sehingga nilai akumulasi penyusutan yang ada dikelola oleh BPKAD. Pengurus Aset Dinas Pekerjaan Umum Provinsi Sulawesi Utara mengaku belum pernah mencatat penyusutan karena belum adanya prosedur dan petunjuk teknis penyusutan aset tetap yang diatur dalam kebijakan akuntansi aset tetap pemerintah daerah Sulawesi Utara, namun aset yang ada di SKPD ini memiliki masa manfaat sesuai dengan Keputusan Menteri Keuangan nomor 59/KMK.6/2013 Tentang Tabel Masa Manfaat Dalam Rangka Penyusutan Barang Milik Negara Berupa Aset Tetap Pada Entitas Pemerintah Pusat. Perhitungan Penyusutan Aset Tetap dilakukan dengan menggunakan metode garis lurus "Straight line Metodh" sebagai berikut :

Dari Kartu Inventaris Barang (KIB) diketahui: Harga perolehan Excavator menurut sub buku besar yang telah sesuai dengan KIB adalah sebesar Rp715.867.732, diperoleh dengan pembelian pada tahun 2015, kondisi aset tetap dalam keadaan baik, kebijakan Akuntansi mengenai masa manfaat berdasarkan peraturan menteri keuangan 59/KMK.6/2013 menetapkan excavator yang tergolong dalam alat besar darat mempunyai masa manfaat 10 tahun dan disusutkan per individu dengan menggunakan metode garis lurus :

Rp715.867.732 : $10=$ Rp71.586.773,2

Maka nilai penyusutan pertahun sebesar Rp71.586.773,2 terhadap aset tetap tersebut. Perhitungan demikian diterapkan pada seluruh aset tetap yang terdapat di Dinas Pekerjaan Umum Provinsi Sulawesi Utara.

Dalam Laporan Penyusutan Aset Tetap dilakukan kebijakan penyusutan persemester sehingga nilai penyusutan pertahun dibagi dua sebagai berikut :

Rp715.867.732: $10=\operatorname{Rp} 71.586 .773,2$

Rp71.586.773,2 : $2=\operatorname{Rp} 35.793 .387$

Sehingga nilai penyusutan yang tercatat di laporan penyusutan adalah Rp35.793.387. Perhitungan demikian diterapkan pada seluruh Aset Tetap yang terdapat di Dinas Pekerjaan Umum Provinsi Sulawesi Utara.

Penyusutan Per Semester = Nilai Perolehan : Masa Manfaat 2

Akumulasi Penyusutan Per 31 Desember = Nilai Penyusutan Pertahun + Akumulasi Penyusutan Per 01 januari

Nilai Buku = Nilai Perolehan - Akumulasi Penyusutan Per 31 Desember.

\subsection{Pembahasan}

Berikut ini disajikan hasil analisis penerapan akuntansi penyusutan aset tetap yang diimplementasikan oleh Dinas Pekerjaan Umum Provinsi Sulawesi Utara dan Pernyataan Standar Akuntansi Pemerintah nomor 07 yang tertuang di dalam Peraturan Pemerintah Nomor 71 Tahun 2010 tentang Standar Akuntansi Pemerintah. 


\section{Tabel 1}

Penggunaan Metode Penyusutan

\begin{tabular}{|l|l|l|}
\hline \multicolumn{1}{|c|}{ Dinas PU } & \multicolumn{1}{|c|}{ PSAP no 7 } & \multicolumn{1}{|c|}{ Keterangan } \\
\hline $\begin{array}{l}\text { Menggunakan Metode Penyusutan } \\
\text { garis lurus, "Straigh Line Method" }\end{array}$ & $\begin{array}{l}\text { Metode Penyusutan yang di } \\
\text { anjurkan : }\end{array}$ & Sesuai \\
Metode ini diterapkan terhadap & $\begin{array}{l}\text { 1. metode garis lurus } \\
\text { seluruh aset tetap dalam kelompok } \\
\text { kendaraan dan perlatan pada }\end{array}$ & \multicolumn{1}{c}{ metode saldo menurun } \\
bidang Kimpraswil PU SULUT. & $\begin{array}{l}\text { 3. metode unit produksi. } \\
\text { Entitas pemerintah dapat } \\
\text { memilih salah satu dari ketiga }\end{array}$ & \\
& metode diatas. & \\
\hline
\end{tabular}

(Sumber : Data Olahan 2017)

Berdasarkan tabel 1, Perhitungan yang digunakan dalam proses penyusutan aset tetap menggunakan metode penyusutan garis lurus "Straight line method". Penggunaan metode ini sesuai dengan yang anjurkan didalam Pernyataan Standar Akuntansi Pemerintah nomor 07.

\section{Tabel 2}

Penentuan Masa Manfaat Aset Tetap

\begin{tabular}{|l|l|l|}
\hline Dinas PU & \multicolumn{1}{|c|}{ PSAP no 7 } & Keterangan \\
\hline Penetuan masa manfaat aset tetap & entitas pemerintah dapat & sesuai \\
mengacu pada kepada peraturan & mengacu pada tabel masa & \\
menteri keuangan nomor & manfaat aset yang diatur dalam & \\
59/KMK.6/2013. Diaplikasikan & peraturan menteri keuangan & \\
kepada aset kelompok peralatan & nomor 59/KMK.6/2013. & \\
dan mesin. & & \\
\hline
\end{tabular}

(Sumber : Data Olahan 2017)

Dalam entitas pemerintah penentuan masa manfaat suatu aset telah ditetapkan untuk mempermudah dalam menentukan masa manfaat suatu aset. Penentuan masa manfaat aset tetap dilakukan dengan berpedoman pada masa manfaat aset tetap yang disajikan dalam tabel masa manfaat aset tetap dalam Peraturan Menteri Keuangan nomor 59/KMK.6/2013. Hal demikian juga diterapkan pada Dinas Pekerjaan Umum Provinsi Sulawesi Utara kelompok aset peralatan dan mesin Bidang Pemukiman dan Prasaranan Wilayah seperti yang digambarkan dalam tabel 2.

Tabel 3

Penentuan Nilai Buku Aset

\begin{tabular}{|ll|l|l|}
\hline \multicolumn{2}{|c|}{ Dinas PU } & \multicolumn{1}{|c|}{ PSAP no 7 } & Keterangan \\
\hline Nilai Buku Suatu aset & Nilai Buku Suatu aset ditentukan & sesuai \\
ditentukan & berdasarkan & berdasarkan Nilai Perolehan aset & \\
Nilai Perolehan aset & dikurangi akumulasi penyusutan & \\
dikurangi $\quad$ akumulasi & & \\
penyusutan per 31 & & \\
Desember. & & & \\
\hline
\end{tabular}

(Sumber : Data Olahan 2017)

Dalam PSAP No 7 Dijelaskan bahwa Nilai buku aset, dihitung dari biaya perolehan suatu aset setelah dikurangi akumulasi penyusutan. Hal ini sesuai dengan penentuan nilai 
buku aset pada Dinas Pekerjaan Umum Provinsi Sulawesi Utara yaitu dengan mengurangi nilai perolehan aset dengan akumulasi penyusutan seperti yang di jelaskan pada tabel 3 .

Tabel 4

Lembaga Pembuat Perhitungan Penyusutan

\begin{tabular}{|c|c|c|}
\hline Dinas PU & PSAP no 7 & Keterangan \\
\hline $\begin{array}{l}\text { Aktivitas perhitungan dan } \\
\text { pelaporan akuntansi } \\
\text { penyusutan aset tetap } \\
\text { dilakukan oleh BPKAD } \\
\text { Provinsi Sulawesi Utara. }\end{array}$ & $\begin{array}{l}\text { Asas Kemandirian dalam PP No } 71 \\
\text { tahun } 2010 \text { mengharuskan setiap } \\
\text { entitas pemerintah sebagai lembaga } \\
\text { mandiri yang dapat mengatur } \\
\text { seluruh aktivitas akuntansinya } \\
\text { secara mandiri. }\end{array}$ & Belum Sesuai \\
\hline
\end{tabular}

(Sumber : Data olahan 2017)

Berdasarkan tabel 4, dijelaskan bahwa aktivitas perhitungan penyusutan dan pelaporan akuntansi penyusutan di laksanakan oleh Badan Pengelola Keuangan dan Aset Daerah (BPKAD) Provinsi Sulawesi Utara, hal ini bertentangan dengan asumsi kemandirian entitas yang tertuang di dalam Peraturan Pemerintah Nomor 71 tahun 2010, Asumsi kemandirian entitas, berarti bahwa setiap unit organisasi dianggap sebagai unit yang mandiri dan mempunyai kewajiban untuk menyajikan laporan keuangan sehingga tidak terjadi salah saji antar unit instansi pemerintah dalam pelaporan keuangan.

\section{KESIMPULAN DAN SARAN}

\subsection{Kesimpulan}

Dalam aktivitas akuntansi penyusutan aset pada Dinas Pekerjaan Umum Provinsi Sulawesi Utara yang dilakukan oleh BPKAD Prov. Sulawesi Utara, dilakukan dengan menggunakan metode pencatatan garis lurus "straight line method" hal ini sesuai dengan PSAP no 7. Penetapan Masa Manfaat aset mengacu pada Masa Manfaat Aset Tetap yang disajikan dalam Tabel Masa Manfaat Aset Tetap dalam Peraturan Menteri Keuangan nomor 59/KMK.6/2013. Dalam aktivitas penyusutan aset tetap, Dinas Pekerjaan Umum Provinsi Sulawesi Utara secara kelembagaan tidak melakukan pencatatan atas aset tetapnya namun dilakukan oleh lembaga lain dalam hal ini Badan Pengelola Keuangan dan Aset Daerah (BPKAD) Provinsi Sulawesi utara dan hal ini tidak sesuai dengan Peraturan Pemerintah Nomor 71 Tahun 2010. Ketidaksesuaian ditinjau dari asumsi kemandirian entitas dalam PP no 71 Tahun 2010.

\subsection{Saran}

Diharapkan Dinas Pekerjaan Umum Provinsi Sulawesi Utara dapat menerapkan peyusutan aset tetap secara mandiri sesuai dengan ketentuan PP no 71 Tahun 2010 mengenai Asumsi kemandirian entitas, yang berarti bahwa setiap unit organisasi dianggap sebagai unit yang mandiri dan mempunyai kewajiban untuk menyajikan laporan keuangan sehingga tidak terjadi salah saji laporan antar unit instansi pemerintah dalam pelaporan keuangan.

Pemerintah perlu memberikan sosialisasi aturan beserta pelatihan teknis dalam bentuk workshop kepada para pegawai dalam menerapkan penyusutan aset tetap, agar para pegawai dapat memahami pelaksanaan teknis aktivitas penyusutan dari perhitungan penyusutan hingga pelaporan penyusutan aset tetap.

\section{DAFTAR PUSTAKA}

Mursyidi. 2009. Akuntansi Pemerintahan di Indonesia. PT. Refika Aditama. Bandung. Pontoh, Winston. 2013. Akuntansi: Konsep dan Aplikasi. Halaman Moeka, Jakarta Barat. 
Peraturan Pemerintah Republik Indonesia Nomor 71 Tahun 2010. 2012. Standar Akuntansi Pemerintahan, Komite Standar Akuntansi Pemerintah. Jakarta. Salemba Empat.

Pernyataan Standar Akuntansi Pemerintah Nomor 07 tentang Akuntansi Aset tetap.

Reeve, James M. Warren S, Carl. Duchac E, Jonathan. Wahyuni T,Ersa. Soepriyanto, Gatot. Jusuf A, Amir. \& Djakman, Chaerul. 2013. Pengantar Akuntansi Indonesia Buku 2. Indeks. Jakarta.

Sujarweni, V. Wirtna. 2015. Akuntansi Sektor Publik. Pustaka Baru Press. Yogyakarta.

Soepiansyah M, Ady. 2014. Implementasi Pernyataan Standar Akuntansi Pemerintah No. 07 Tentang Akuntansi Penyusutan Aset Tetap Pada Kantor Satuan Polisi Pamong Praja Provinsi Kalimantan Barat. Pontianak. Jurnal Kajian Ilmiah Akuntansi Fakultas Ekonomi UNTAN (KIAFE) Vol 3, No 2.

Tipan, Akhyar. 2016. Analisis Perlakuan Akuntansi Aset Tetap Pada Dinas Pekerjaan Umum Provinsi Sulawesi Utara. Manado. Jurnal Riset Akuntansi Going Concern Vol 11, No. 1

Yusuf, M. 2011. 8 Langkah Pengelolaan Aset Daerah Menuju Pengelolaan Keuangan Daerah Terbaik. Cetakan Kedua. Salemba Empat. Jakarta. 